\title{
Mixtures of natural antimicrobials can reduce Campylobacter jejuni, Salmonella enterica and Clostridium perfringens infections and cellular inflammatory response in MDCK cells
}

Igori Balta ${ }^{1,2,3^{*}+}$, Adela Marcu ${ }^{3^{*}+}$, Mark Linton' ${ }^{1}$, Carmel Kelly ${ }^{1}$, Ozan Gundogdu' 4 , Lavinia Stef ${ }^{3}$, loan Pet ${ }^{3}$, Patrick Ward ${ }^{5}$, Myriam Deshaies ${ }^{5}$, Todd Callaway ${ }^{6}$, Phittawat Sopharat ${ }^{5}$, Gratiela Gradisteanu-Pircalabioru ${ }^{7}$ and Nicolae Corcionivoschi ${ }^{1,2,3^{*}+}$ [D

\begin{abstract}
Background: The classification of natural antimicrobials as potential antibiotic replacements is still hampered by the absence of clear biological mechanisms behind their mode of action. This study investigated the mechanisms underlying the anti-bacterial effect of a mixture of natural antimicrobials (maltodextrin, citric acid, sodium citrate, malic acid, citrus extract and olive extract) against Campylobacter jejuni RC039, Salmonella enterica SE 10/72 and Clostridium perfringens ATCC ${ }^{\circledR} 13124$ invasion of Madin-Darby Canine Kidney cells (MDCK).

Results: Minimum sub-inhibitory concentrations were determined for Campylobacter jejuni (0.25\%), Salmonella enterica $(0.50 \%)$ and Clostridium perfringens (0.50\%) required for the in vitro infection assays with MDCK cells. The antimicrobial mixture significantly reduced the virulence of all three pathogens towards MDCK cells and restored the integrity of cellular tight junctions through increased transepithelial resistance (TEER) and higher expression levels of ZO-1 (zonula occludens 1) and occludin. This study also identified the ERK (external regulated kinase) signalling pathway as a key mechanism in blocking the pro-inflammatory cytokine production (IL-1 $\beta$, IL-6, IL-8, TNF- $\alpha$ ) in infected cells. The reduction in hydrogen peroxide $\left(\mathrm{H}_{2} \mathrm{O}_{2}\right)$ production and release by infected MDCK cells, in the presence of the antimicrobial mixture, was also associated with less tetrathionate formed by oxidation of thiosulphate $(p<0.0001)$.

Conclusion: The present study describes for the first time that mixtures of natural antimicrobials can prevent the formation of substrates used by bacterial pathogens to grow and survive in anaerobic environments (e.g. tetrathionate).
\end{abstract}

\footnotetext{
*Correspondence: igori.balta@gmail.com; adelamarcu@usab-tm.ro; nicolae.

corcionivoschi@afbini.gov.uk

${ }^{\dagger}$ Nicolae Corcionivoschi, Igori Balta and Adela Marcu contributed equally

to this work

1 Food Microbiology, Bacteriology Branch, Veterinary Sciences Division,

Agri-Food and Biosciences Institute, 18a Newforge Lane, Belfast BT9 5PX,

Northern Ireland, UK

${ }^{3}$ Faculty of Bioengineering of Animal Resources, Banat University

of Agricultural Sciences and Veterinary Medicine-King Michael I

of Romania, 300645 Timisoara, Romania

Full list of author information is available at the end of the article
}

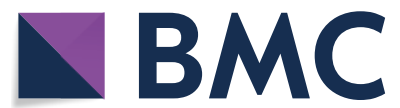

(c) The Author(s) 2021. This article is licensed under a Creative Commons Attribution 4.0 International License, which permits use, sharing, adaptation, distribution and reproduction in any medium or format, as long as you give appropriate credit to the original author(s) and the source, provide a link to the Creative Commons licence, and indicate if changes were made. The images or other third party material in this article are included in the article's Creative Commons licence, unless indicated otherwise in a credit line to the material. If material is not included in the article's Creative Commons licence and your intended use is not permitted by statutory regulation or exceeds the permitted use, you will need to obtain permission directly from the copyright holder. To view a copy of this licence, visit http://creativeco mmons.org/licenses/by/4.0/. The Creative Commons Public Domain Dedication waiver (http://creativecommons.org/publicdomain/ zero/1.0/) applies to the data made available in this article, unless otherwise stated in a credit line to the data. 
Moreover, we provide further insights into pathogen invasion mechanisms through restoration of cellular structures and describe their ability to block the ERK-MAPK kinase pathway responsible for inflammatory cytokine release

Keywords: C. jejuni, S. enterica, C. perfringens, Natural antimicrobials, Hydrogen peroxide, ERK kinase, MDCK cells, Virulence

\section{Background}

Food-borne bacterial illnesses affect approximately 226 million people each year $[1,2]$. Infections caused by foodborne zoonotic agents, such as Campylobacter spp., Salmonella spp., and Clostridium spp., are associated with high morbidity rates worldwide in both humans and animals [3]. Household pets can also contract these pathogens through non-food sources, such as the environment, pet feed and contact with infected animals or humans [4].

Poultry meat is considered the main source of Campylobacter for human infections, however, the presence of this bacterium in dogs and cats increases significant public health concerns as pets can potentially be considered a transmission vector [5]. In dogs, Campylobacter spp. infection can trigger acute polyradiculoneuritis (APN), a canine version of Guillen-Barre Syndrome (GBS) which displays similar pathologies [6]. In companion animals, salmonellosis is mainly caused by Salmonella enterica serovar Typhimurium and specifically, in dogs is transmitted via the consumption of raw feeds rather than processed feeds [7]. Following infection, the bacterium is primarily isolated from the mesenteric lymph nodes and intestinal tracts. Dogs can be asymptomatic carriers for more than 42 days, during which time the pathogen is easily transmissible to humans [8]. Clostridium perfringens is mainly associated with acute haemorrhagic diarrhoea syndrome (AHDS) in dogs [9]. Symptoms normally are a mild or self-limiting diarrhoea, but in some cases can also lead to fatal acute haemorrhagic diarrhoea. In cases of severe haemorrhagic canine gastroenteritis,a severe necrotising inflammation of the intestinal tract epithelium can occur which can lead to rapid mortality [10].

Mixtures of natural antimicrobials (e.g. plant extracts or organic acids) have been shown to prevent colonisation or infection of the epithelium in a variety of hosts, including ruminants, monogastrics and aquatic crustaceans [11-16]. The anti-infective mode of action occurs by improving the host gastrointestinal epithelium integrity and downregulating some of the vital bacterial virulence factors (e.g. motility, bacterial polysaccharides). At the host level, the antimicrobial mode of action was related to the restoration of tight junction (TJ) integrity, and diminished inflammation via a reduction in proinflammatory cytokine secretion throughout the gut [15]. Common canine pathogens (e.g., Campylobacter spp.,
Salmonella spp., and Clostridium spp.) are inhibited by mixtures of these natural antimicrobials $[17,18]$.

Understanding the biological mechanism by which natural antimicrobials reduce bacterial infections and reduce epithelial inflammation is essential to establish best practices for end users, and ensure that their specific anti-bacterial effect can be consistently utilized. Bacterial pathogens, including Campylobacter, can disrupt epithelial tight junctions (TJ) upon infection [19] and will stimulate the host NADPH oxidases to produce and release extra and intra-cellular hydrogen peroxide $\left(\mathrm{H}_{2} \mathrm{O}_{2}\right)$ [20]. At the cytoplasmic level, consequences of $\mathrm{H}_{2} \mathrm{O}_{2}$ production include the activation of the extracellular signalregulated kinase (ERK), which is central to the signalling cascade leading to pro-inflammatory cytokine production [21, 22]. The involvement of the ERK pathways in pro-inflammatory events was previously described [23] as being closely related to bacterial infection [24]. Other natural antimicrobial extracts (e.g., ambuic acid) have an anti-inflammatory action that blocks activation of the ERK signalling pathway in lipopolysaccharide (LPS)treated cells [25].

Natural antimicrobials can serve as both treatment and prophylaxis by preventing a drop in trans-epithelial resistance and restoring cellular TJ integrity [26]. The present study investigated the possible role of natural antimicrobials and their anti-pathogenic effect against C. jejuni RC039, S. enterica SE 10/72 and C. perfringens ATCC $^{\circledR} 13124$ in canine derived Madin-Darby Canine Kidney cells (MDCK). Further, we hypothesized that natural antimicrobials could prevent bacterially-induced oxidative stress and restore cellular structure integrity (including TJ or ZO-1 and occludin) damaged as a result of cytoplasmic $\mathrm{H}_{2} \mathrm{O}_{2}$ release, and could block ERK activation and prevent inflammation and pro-inflammatory cytokine release. It is clear now that attenuation of ROS induced oxidative stress induced by the antimicrobial mixture also led to a decrease in host-induced molecules (e.g. tetrathionate) a well-known electron acceptor used by bacterial pathogens to survive in oxygen depleted environments [27].

\section{Results}

\section{Establishing the sub-inhibitory concentrations}

First we aimed to establish the anti-pathogenic effect of a natural antimicrobial mixture (Auraguard) and 
to determine the sub-inhibitory concentrations for $C$. jejuni, S. enterica and C. perfringens. Strong antimicrobial activity was detected against all three species (Fig. 1). The minimum inhibitory concentrations were $0.25 \%$ for C. jejuni, and $0.50 \%$ for S. enterica and C. perfringens. The minimum bactericidal concentrations were noted at $0.50 \%$ for C. jejuni, at $1 \%$ for S. enterica and $C$. perfringens (Table 1 ). Based on these results we used concentrations of $0.25 \%$ for $C$. jejuni, and $0.5 \%$ for $S$. enterica and $C$. perfringens to test their inhibitory effect in preventing the infection of MDCK cells.

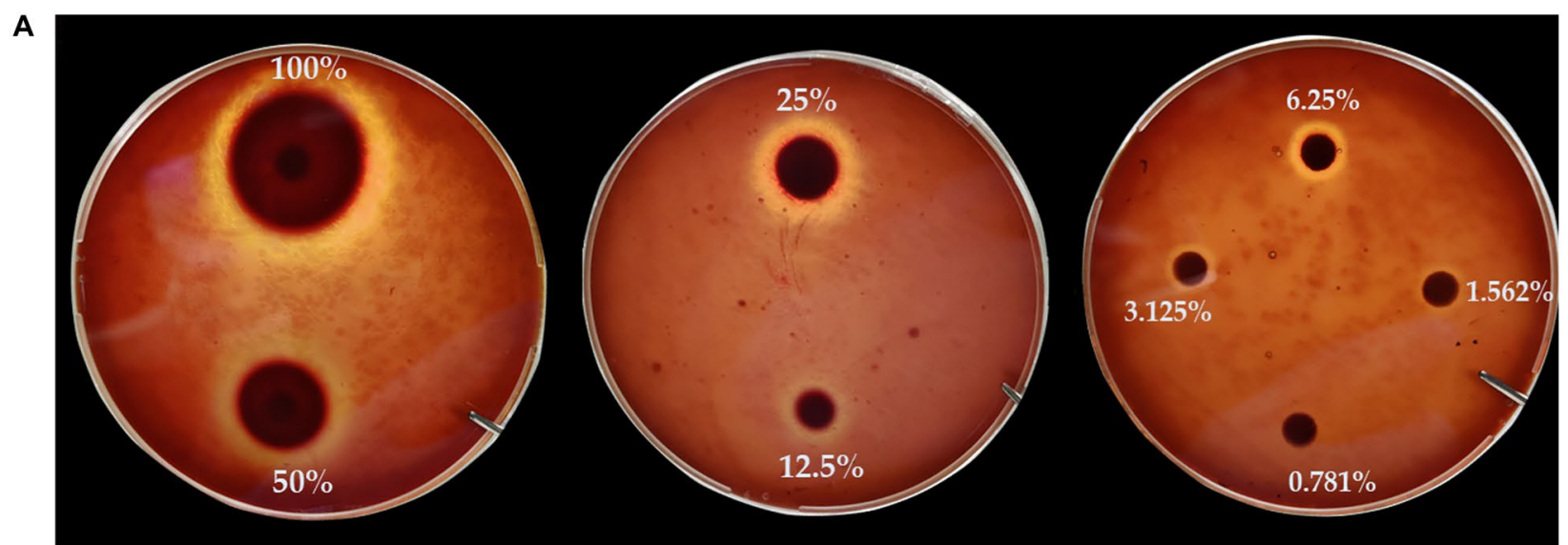

B

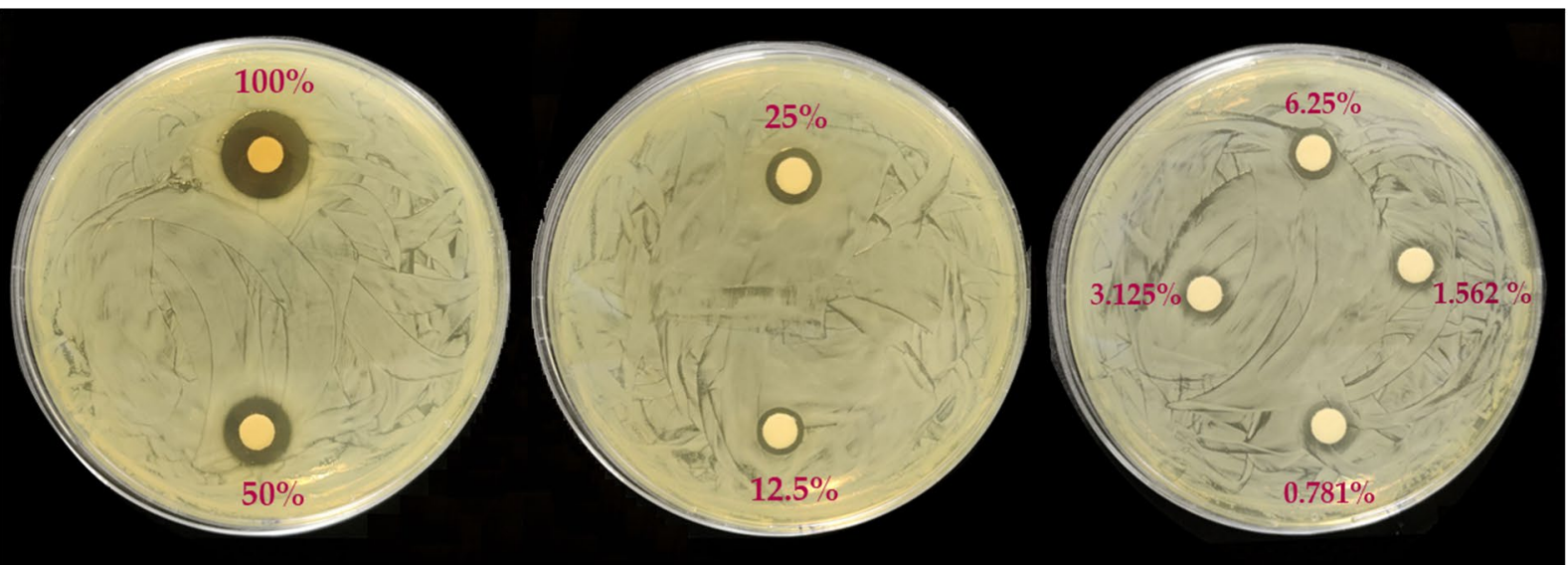

C

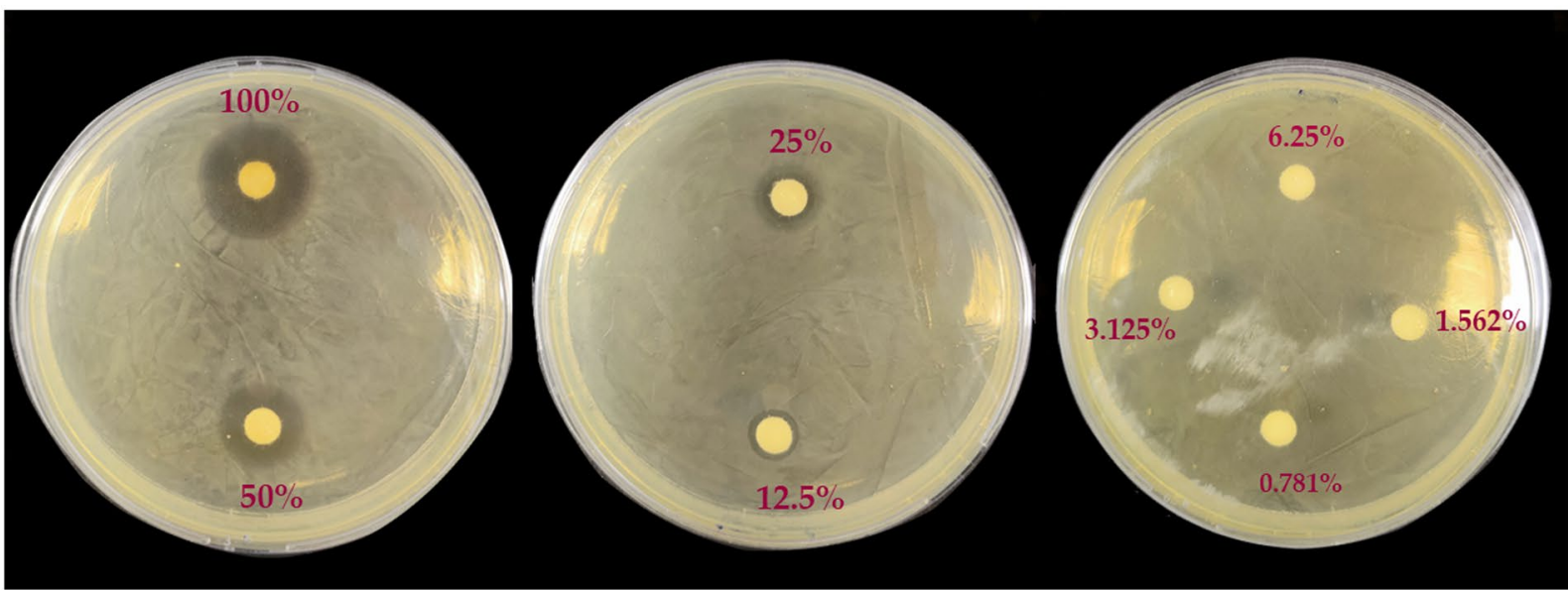

Fig. 1 Representative Petri plate images showing the inhibitory zones at different concentrations of Auraguard against C. jejuni (A), S. enterica (B) and C. perfringens ( $\mathbf{C}$ ) 
Table 1 Minimum inhibitory concentration (MIC) and minimum bactericidal concentration (MBC) activity of the antimicrobial mixture

\begin{tabular}{lll}
\hline Strains & MIC (\%) & MBC (\%) \\
\hline Campylobacter jejuni (RC039) & 0.25 & 0.50 \\
Salmonella enterica (SE10/72) & 0.50 & 1 \\
Clostridium perfringens (ATCC ${ }^{\circledR} 13124^{\mathrm{TM}}$ ) & 0.50 & 1 \\
\hline
\end{tabular}

\section{Auraguard prevents the in vitro infection of MDCK cells by $C$. jejuni, S. enterica and C. perfringens}

In vitro infection assays were performed to identify if there was a direct effect on cellular invasion by Auraguard added at $0.25 \%$ and $0.50 \%$. Exposure of MDCK cells prior to infection reduced $(\mathrm{p}=0.03)$ the invasion of C. jejuni at concentrations of only $0.25 \%$ (Fig. 2B) with no significant decrease in adhesion (Fig. 2A). In the case of S. enterica there was a impact on both adhesion (Fig. 2C, $\mathrm{p}<0.0001$ ) and invasion (Fig. $2 \mathrm{D}, \mathrm{p}=0.0001$ ) after pretreatment of MDCK cells with $0.50 \%$ Auraguard. A similar pattern was observed in C. perfringens infections with impacts on both bacterial adhesion (Fig. $2 \mathrm{E}, \mathrm{p}=0.02$ ) and cell invasion (Fig. 2F, p=0.004), when $0.50 \%$ Auraguard was used to pre-treat the epithelial cells. Overall, results suggest that Auraguard prevented the adhesion and invasion of MDCK cells potentially by restoring the integrity of the cellular structures damaged by bacterial infection.

The effect of Auraguard on paracellular permeability, TEER, ZO-1 and occludin expression in infected MDCK cells Following the in vitro infection assay results we investigated the impact of Auraguard on cell membrane restoration leading to reduced infectivity. Treatment of MDCK cells with $0.25 \%$ and $0.5 \%$ Auraguard decreased the paracellular calcein flux indicating improvements $(* * * * * 0.0001)$ in cellular membrane integrity (Fig. 3A). We expected that an improvement in membrane permeability should be accompanied by an improvement of cellular tight junctions quantified by measuring the trans-epithelial resistance. Our results show that infection of MDCK cells with C. jejuni, S. enterica and $C$. perfringens decreased the trans-epithelial resistance of cell monolayers at $3 \mathrm{~h}$ post-infection (Fig. 3B). In contrast, Auraguard exposure of cells led to increased TEER values reducing the detrimental effect of pathogen infection $(p<0.0001)$. To further prove that Auraguard has a beneficial impact on cellular membrane structures we measured the effect on the mRNA levels of ZO-1 (Fig. 3C) and occludin (Fig. 3D). Results demonstrate that following infection with $C$. jejuni the addition of $0.25 \%$ Auraguard increased the expression of ZO-1 $(\mathrm{p}=0.003)$ and occludin $(\mathrm{p}=0.006)$ in cells.
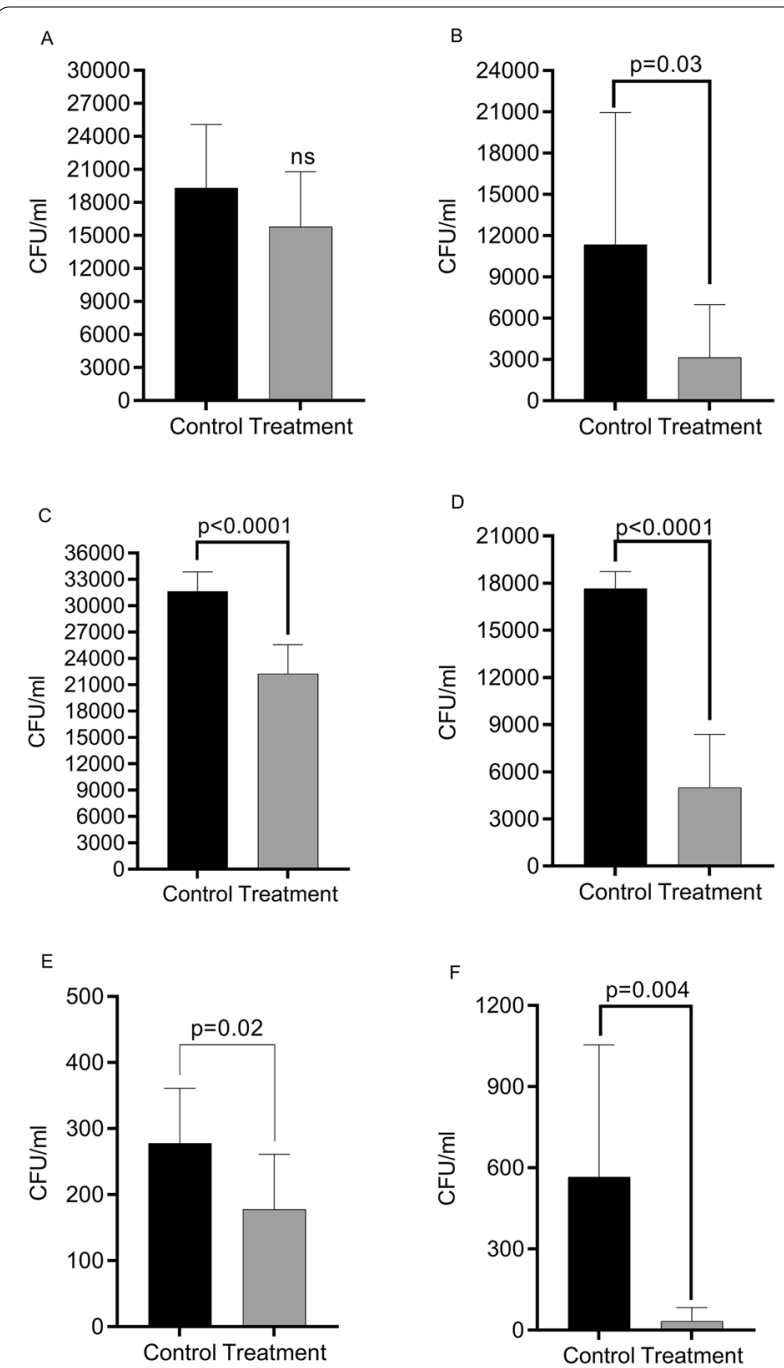

Fig. 2 In vitro adhesion and invasion of Auraguard pre-treated (0.25\% and 0.50\%) MDCK cells by C. jejuni RC039 (A-adhesion, Binvasion), S. enterica (C-adhesion, D-invasion) and C. perfringens (E-adhesion, F-invasion). Results are expressed as CFU/ml. Error bars represent the standard deviation of means from three different experiments, each containing triplicate samples

Similarly, an increase in ZO-1 and occluding expression $(\mathrm{p}=0.0005$ and $\mathrm{p}=0.0002$, respectively) occurred when MDCK cells were infected with $S$. enterica and exposed to $0.5 \%$ Auraguard. Infections with $C$. perfringens of MDCK cells pre-treated with $0.5 \%$ Auraguard also led to a significant increase in ZO-1 expression $(\mathrm{p}<0.0001)$ and occludin $(\mathrm{p}<0.0001)$. Collectively, these results suggest that Auraguard has a positive and restorative impact on cellular membrane integrity and prevents infection of epithelial cells. 


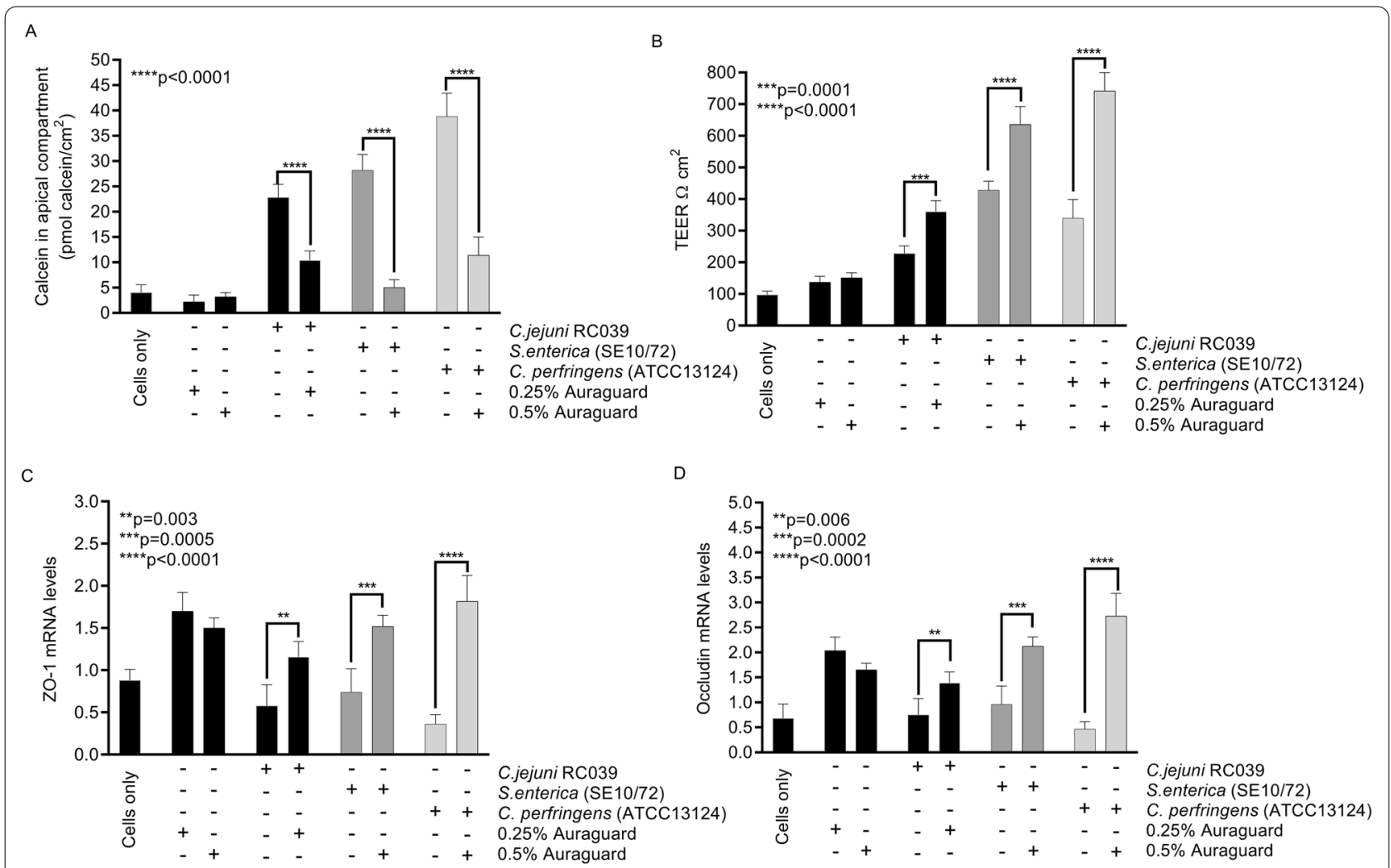

Fig. 3 The effect of Auraguard on infected MDCK cells paracellular membranes calcein flux (A), TEER (B), ZO-1 (C) and occluding expression (D) during infection with C. jejuni, S. enterica or C. perfringens. Data are presented as means (SD) of triplicate independent samples and experiments

\section{Auraguard blocks the ERK signal transduction pathway,} prevents inflammation and the intra and extracellular $\mathrm{H}_{2} \mathrm{O}_{2}$ release in in MDCK cells but not bacterial invasion

Following the initial results indicating that Auraguard was involved in membrane restoration, we investigated if the ERK signalling pathway was involved in membrane restoration of infected MDCK cells. Infection of nonAuraguard treated MDCK cells with $C$. jejuni (Fig. 4A) led to $\approx 25 \mathrm{nmol} \mathrm{H}_{2} \mathrm{O}_{2}$ being secreted in the extracellular space (released $\mathrm{H}_{2} \mathrm{O}_{2}$ ) compared with $\approx 8 \mathrm{nmol} \mathrm{H}_{2} \mathrm{O}_{2}$ $(\mathrm{p}=0.0002)$ in cells pre-treated with $0.25 \%$ Auraguard, which was similar to uninfected controls (Fig. 4A). Infections with $S$. enterica generated $\approx 43 \mathrm{nmol} \mathrm{H}_{2} \mathrm{O}_{2}$ which were reduced to $\approx 12 \mathrm{nmol} \mathrm{H}_{2} \mathrm{O}_{2}(\mathrm{p}<0.0001)$ in Auraguard pre-treated cells (Fig. 4A). Similarly, infections with $C$. perfringens (Fig. 4A) led to a decrease in $\mathrm{H}_{2} \mathrm{O}_{2}$ concentrations from $35 \mathrm{nmol} \mathrm{H}_{2} \mathrm{O}_{2}$ to $14 \mathrm{nmol} \mathrm{H}_{2} \mathrm{O}_{2}$ in the presence of $0.50 \%$ Auraguard $(\mathrm{p}=0.0003)$. Auraguard treatment also led to significant decrease in intracellular $\mathrm{H}_{2} \mathrm{O}_{2}(\mathrm{p}<0.0001)$ (Fig. 4B). The presence of the ERK signal transduction pathway inhibitor (PD98059) also led to decrease in $\mathrm{H}_{2} \mathrm{O}_{2}$ both extra and intracellularly (Fig. 4A, B). The unavailability of $\mathrm{H}_{2} \mathrm{O}_{2}$ caused the restoration of TEER when cells were exposed to Auraguard or PD98059
(Fig. 4C), significantly decreased paracellular permeability (Fig. 4D) and restored the expression of $\mathrm{ZO}-1$ (Fig. 4E). Our results also suggest that the antimicrobial mixture reduces bacterial invasion and diminishes postinfection pro-inflammatory events (Fig. 4F).

The IL-1 $\beta$, IL- 6 , IL-8, TNF- $\alpha$ levels are attenuated in infected MDCK cells by Auraguard via the ERK signal transduction pathway

In order to further examine anti-inflammatory impacts of Auraguard we measured IL-1 $\beta$, IL-6, IL-8, TNF- $\alpha$ secretion by infected MDCK cells. Cells were infected with C. jejuni, S. enterica and C. perfringens and ERK stimulation was assessed in cells treated at $0.25 \%$ and $0.50 \%$ Auraguard during pathogen infection using Western blot. Bacterial infection primed activation of the ERK MAP kinase, but was inhibited by Auraguard at $3 \mathrm{~h}$ following infection (Fig. 5). Our investigation into the role of the ERK signal transduction pathway as the mechanistic tool in reducing the inflammatory effect of bacterial invasion by Auraguard indicated that the modulation of pro-inflammatory gene expression in the MDCK cells was restored to un-infected levels by the pre-treatment with Auraguard and the ERK inhibitor PD98059. Under 

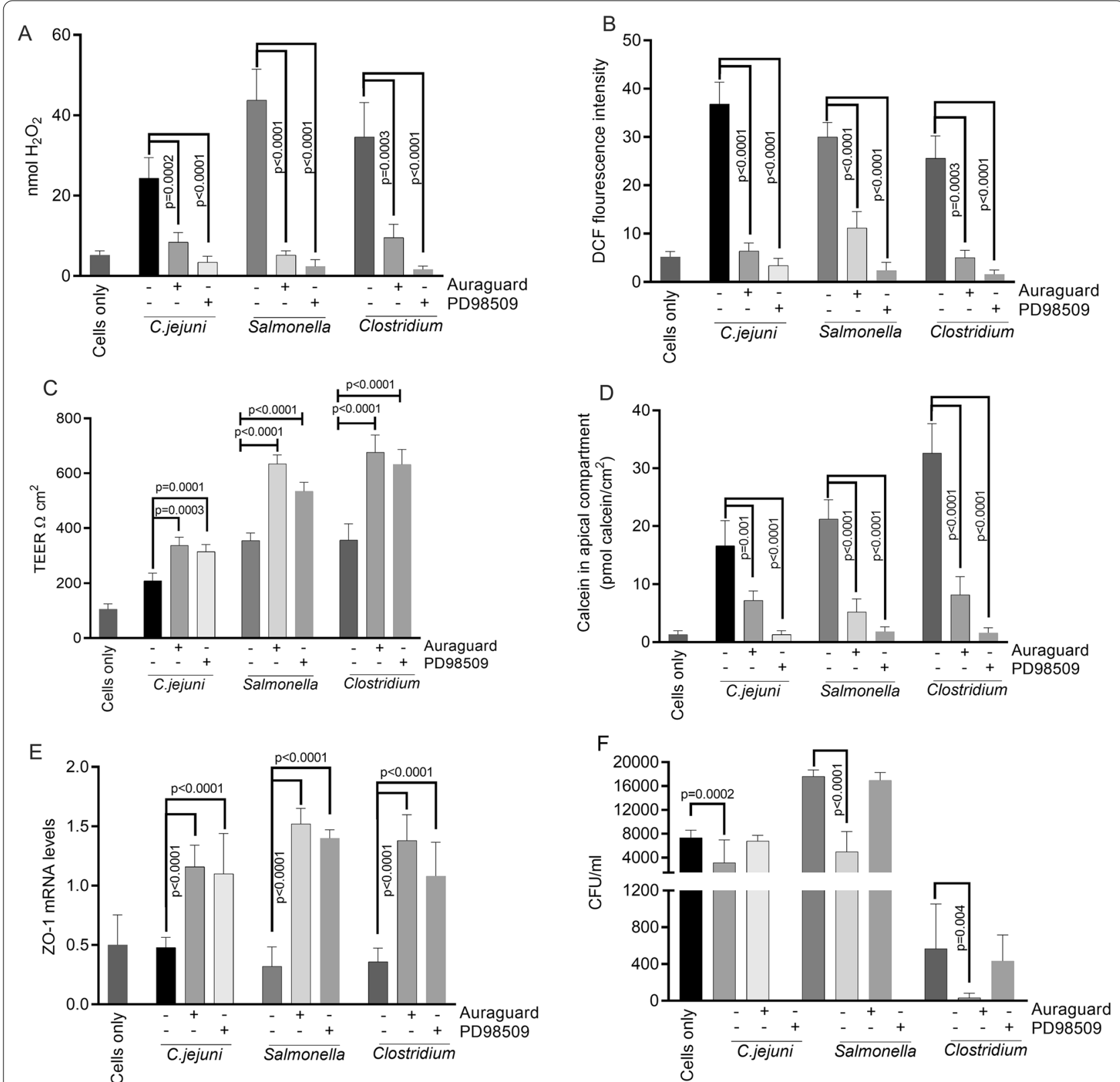

Fig. 4 The effect of Auraguard and the ERK inhibitor PD98059 on infected MDCK cells. The extracellular levels of $\mathrm{H}_{2} \mathrm{O}_{2}$ released by the infected MDCK cells and Auraguard and PD98509 treated MDCK cells are presented in panel A and the intra-cellular levels in panel B. Panel $\mathrm{C}$ shows the effect on MDCK cells TEER with panel D describing the effect on paracellular permeability and in panel E the ZO-1 expression levels. The bacterial infectivity levels are shown in panel F. The significance levels are indicated on the graph. Data are presented as means (SD) of triplicate independent samples and experiments

inflammatory conditions, there was an increased activation of IL-1 $\beta$, IL-6, IL-8, TNF- $\alpha$ in MDCK cells following infection with C. jejuni RC039 (Fig. 6A), S. enterica (Fig. 6B) and C. perfringens (Fig. 6C). Cytokine levels in un-infected cells were below the detection limit (data not shown). However, our results indicate that pre-treatment with Auraguard at levels of $0.25 \%$ for C. jejuni (Fig. 6A) and $0.50 \%$ for S. enterica (Fig. 6B) and C. perfringens (Fig. 6C) reduced levels of IL-1 $\beta$, IL-6, IL-8, TNF- $\alpha$. Reduced inflammation was also observed when cells were pre-treated with the ERK inhibitor PD98059. Firstly, these results show that Auraguard reduced epithelial inflammation as indicated by the cytokine detection levels and secondly, inhibits the ERK signal transduction 


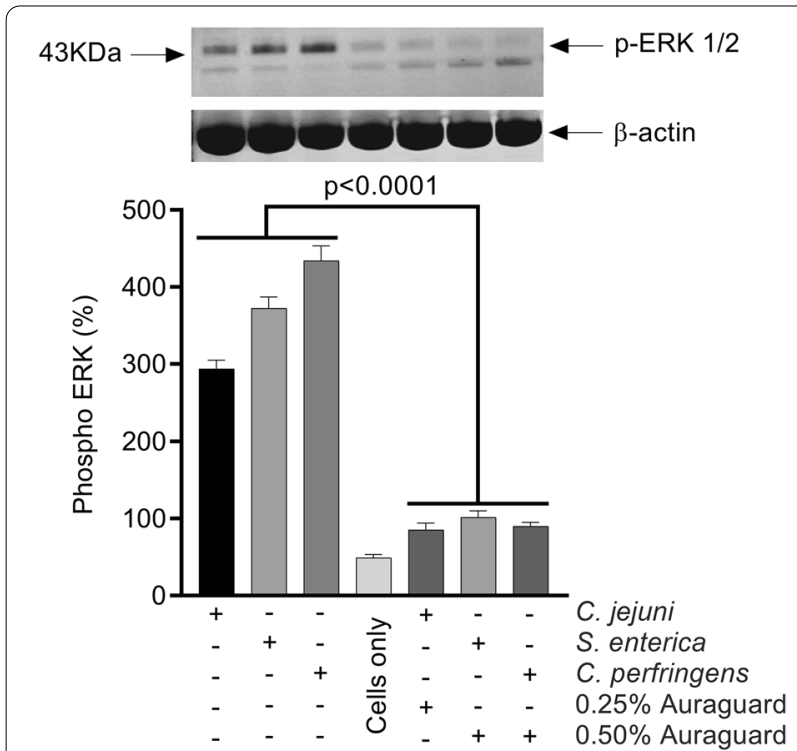

Fig. 5 Inactivation of ERK kinases during C. jejuni, S. enterica and C. perfringens infection of MDCK cells by Auraguard. Activation of ERK was examined by Western immunoblot using monoclonal antibodies specific to the phosphorylated ERK kinase. Equal amounts of protein were added in each lane. Data were standardized on the basis of $\beta$-actin levels. The Student's $t$-test was used to statistically compare the effect of Auraguard. $p$ values are indicated on the graph

pathway in cultured MDCK cells. Overall, these results demonstrate that bacterial infections can activate MAP kinase pathways in cultured MDCK cells and launch proinflammatory events, a mechanism which is independent from bacterial internalization.

\section{Antimicrobial reduced inflammation results in reduction in tetrathionate production}

Treatment with the antimicrobial mixture caused a reduction in cell released reactive oxygen species (ROS) as well as inflammatory cytokine release in infected MDCK cells. This observation suggested that an impact on host driven molecules (e.g. tetrathionate) that support the growth and survival of bacterial pathogens in the gut, was also observed. The addition of $10 \mathrm{mM}$ sodium thiosulfate during infection in vitro led to its conversion to tetrathionate in the supernatants of infected MDCK cells (Fig. 7). However, Auraguard inclusion decreased the levels of tetrathionate detected from 1 to $0.04 \mathrm{mM}$ $(\mathrm{p}<0.0001)$ in $C$. jejuni infected MDCK cell supernatants, from 2.8 to $0.3 \mathrm{mM}$ in S. enterica infected MDCK cell supernatants $(\mathrm{p}<0.0001)$ and from 0.58 to $0.025 \mathrm{mM}$ in $C$. perfringens infected MDCK cells $(\mathrm{p}<0.0001)$. These results indicate that in addition to the impacts of Auraguard on the extracellular and intracellular release of ROS, likely also causing a decrease in secondary molecules produced by the host during inflammation which

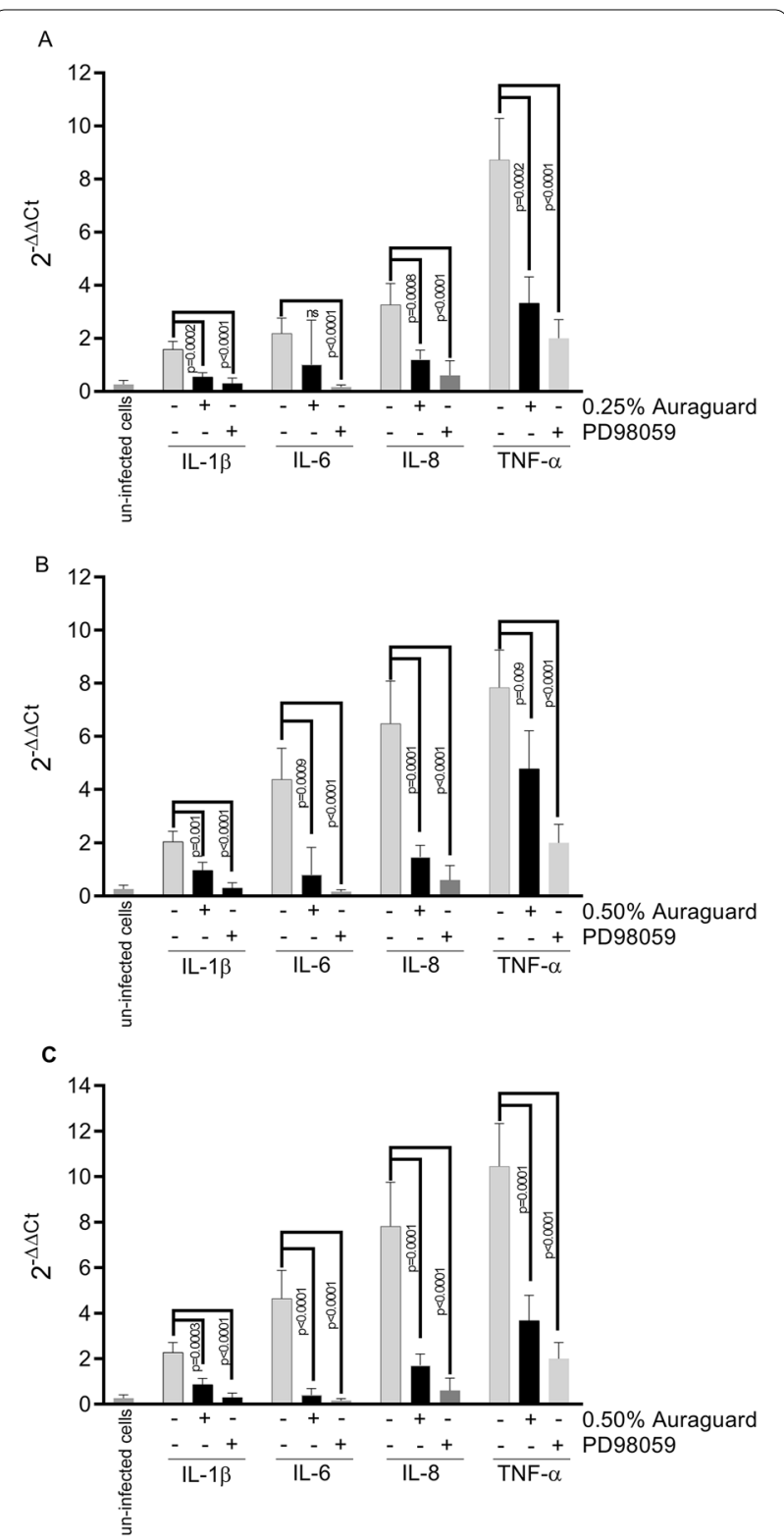

Fig. 6 Modulation of pro-inflammatory genes expression (IL-1 $\beta$, IL-6, IL-8, TNF-a) in infected MDCK cells pre-exposed to $0.25 \%$ and $0.5 \%$ Auraguard or $30 \mu \mathrm{M}$ of PD98059. Data are expressed as $2^{-\mathrm{DDCt}}$ where $\mathrm{DCt}=\mathrm{Ct}$ (target gene) $-\mathrm{Ct}$ (housekeeping); values are the mean of three test replicates. Negative samples were given a Ct 38 fictitious value. The Student's t-test was used to statistically compare the effect of Auraguard. $p$ values are indicated on the graph

are used as electron acceptors by bacteria in oxygen depleted environments.

\section{Discussion}

Understanding the biological mechanisms of how natural antimicrobials prevent infection and subsequent inflammation is limited. In certain pathogens 

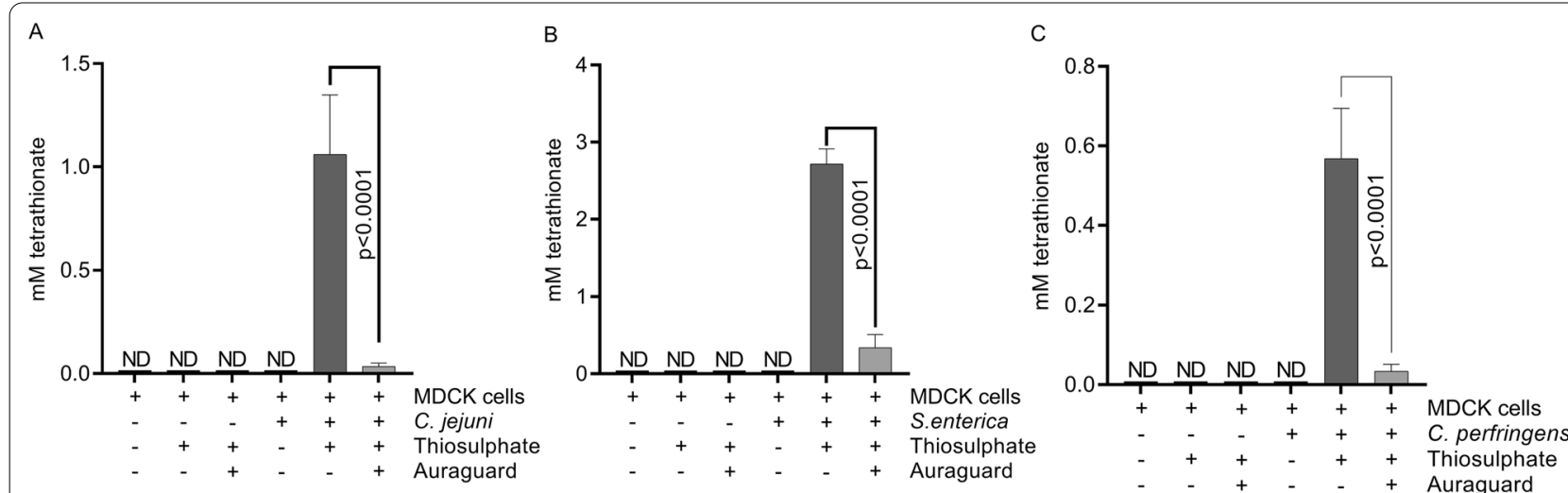

Fig. 7 Tetrathionate levels determined by reverse phase LC-MS from supernatants of infected MDCK cells in the presence of sodium thiosulphate. A C. jejuni, B S. enterica and C C. perfringens. Data represent the mean \pm SEM from three individual experiments

(e.g. Campylobacter jejuni) the mechanism of epithelial cell invasion is mechanistically separated from cellular inflammation [22], involving the extracellular signal transduction pathway (ERK) as an activation switch. ERKs are activated by bacteria through a mechanism involving posttranslational modifications through tyrosine phosphorylation leading to pro-inflammatory cytokine production [28]. Natural antimicrobials have previously been shown to have the ability to block ERK activation and prevent bacterial-induced inflammation [25].

Bacterial pathogens including C. jejuni, S. enterica and C. perfringens are known for their ability to disrupt epithelial barriers and stimulate epithelial production and release of $\mathrm{H}_{2} \mathrm{O}_{2}$ in both the intracellular and extracellular spaces [20,29]. Infection of MDCK cells with $C$. jejuni, S. enterica or C. perfringens generated an increase in $\mathrm{H}_{2} \mathrm{O}_{2}$ detected in the intracellular and extracellular spaces. In MDCK cells the increase in $\mathrm{H}_{2} \mathrm{O}_{2}$ production was associated with enhanced paracellular permeability involving the disruption of ZO-1 protein within the actin cytoskeleton [30, 31]. It has been suggested that the molecular mechanisms controlling and modulating the paracellular permeability required the involvement of occludin and ZO-1 proteins [32, 33]. Inclusion of Auraguard in all infections by $C$. jejuni, S. enterica and $C$. perfringens reduced membrane permeability, increased ZO-1 expression in MDCK cells and reduced $\mathrm{H}_{2} \mathrm{O}_{2}$ production. All these events were followed by reduced invasive abilities of $C$. jejuni, S. enterica and $C$. perfringens in these in vitro cell lines. Organic acids (e.g. citrus extracts) have been shown to reduce the generation of reactive oxygen species thereby preventing oxidative cell injury [34] and when used in combinations will restore TEER and improve cellular tight junctions [26]. The Auraguard-catalysed reduction in $\mathrm{H}_{2} \mathrm{O}_{2}$ released by the infected MDCK cells was linked to the observed increased expression of the $\mathrm{ZO}-1$ protein. The higher levels of $\mathrm{H}_{2} \mathrm{O}_{2}$ reduced occludin and ZO-1 protein content and their involvement in regulating the paracellular permeability $[35,36]$.

It remains unknown how tight junction structures are affected by endogenous $\mathrm{H}_{2} \mathrm{O}_{2}$ production and how natural antimicrobials (e.g. organic acids) impact these structures. Extracellular signal-regulated kinases (ERKs) mediate tight junction disruption, and this mediation takes place in the cytoplasm being restrictively activated by $\mathrm{H}_{2} \mathrm{O}_{2}[21,37]$. Secondly, from a prokaryotic perspective, $\mathrm{H}_{2} \mathrm{O}_{2}$ activates the ERK signal transduction pathway triggering production of pro-inflammatory cytokines in infected intestinal cells [22, 38-40]. Thirdly, organic acids (e.g. Ambuic acid) exert anti-inflammatory effects by blocking the ERK signalling pathway [41]. In this study Auraguard blocked the $\mathrm{H}_{2} \mathrm{O}_{2}$ activated ERK signalling pathway, prevented inflammation and averted the damaging effect on tight junction structures. However, inhibition of the ERK signalling pathway did not prevent invasion of MDCK cells by $C$. jejuni, S. enterica and $C$. perfringens suggesting that the anti-inflammatory mechanism of Auraguard was disconnected from the anti-invasive mechanism. Our study clearly demonstrates that the phospho-deactivation of ERK by Auraguard did not stop bacterial invasion, but did reduce subsequent inflammation. Decoupling of invasion from inflammation was previously described by Campylobacter jejuni where epithelial cell invasion was not necessary to initiate the proinflammatory cascade [22]. Reduction in inflammatory cytokines was associated with increased TEER values, ZO-1 expression, and occludin expression suggesting that these cytokines could modulate tight junction integrity and reduce cellular permeability. Specifically, it has been suggested that downstream effectors of MAP kinase 
signalling pathways mediate a reorganization of cellular barrier function via TNF- $\alpha$ [42]. The cytokine mediation likely coordinates the functions of caveolin-1, involved in cholesterol-rich membrane microdomains [32].

Inflammation of the host epithelium enhances the ability of some bacterial pathogens to grow and survive. Salmonella, similar to other pathogens [20], triggers the production of reactive oxygen species by neutrophils which oxidise thiosulphate into tetrathionate, a product used by Salmonella Typhimurium [43], Yersinia enterocolitica [44] and Campylobacter jejuni [45] to grow in anaerobic conditions. In vivo thiosulphate is produced through oxidation of $\mathrm{H}_{2} \mathrm{~S}$ by the colonic epithelium and further oxidised tetrathionate by commensal bacteria. Along with our observation of the reduction in intra and extracellular $\mathrm{H}_{2} \mathrm{O}_{2}$ release, we also detected a reduction in tetrathionate production as a result of Auraguard-catalyzed inhibition of $\mathrm{H}_{2} \mathrm{O}_{2}$ production. Our results indicate, that in vivo, Auraguard could potentially reduce epithelial inflammation and also prevent the supply of host molecules (e.g. tetrathionate) that could promote the growth and survival of bacterial pathogens in oxygendepleted environments.

\section{Conclusion}

In previous studies we have shown that mixtures of natural antimicrobials are able to reduce bacterial virulence and improve the host defence mechanisms using both in vitro and in vivo infection models $[11-13,15,16,46]$. The current study elucidates the biological mechanism that underlies the anti-pathogenic and anti-inflammatory effects of Auraguard, a mixture of natural antimicrobials. We found that this type of natural antimicrobial mixtures inhibited bacterial internalisation through the restoration of epithelial structures damaged by invasion. Secondly, they act via an anti-inflammatory mechanism involving the deactivation of the ERK signalling pathway through de-phosphorylation. We also show that these mechanisms are similar across pathogenic species as the effects were observed in the case of C. jejuni, S. enterica and $C$. perfringens infections. Possible synergistic mechanisms and interactions between individual components indicate the need for further in vivo investigations are needed to extrapolate these results to animal disease models and possibly to compare their effects to those of various antibiotics.

\section{Material and methods}

Bacterial strains and the mixture of natural antimicrobials Campylobacter jejuni RC039 [47], Salmonella enterica serovar Typhimurium SE10/72 [48], including Clostridium perfringens ATCC $^{\circledR} 13124^{\text {TM }}$ [49] strains, were obtained from the AFBI laboratory collection. C. jejuni RC039 was grown on Blood Agar Base No. 2 (Oxoid Ltd., United Kingdom) supplemented with $5 \%$ (vol/vol) defibrinated horse blood (Aquilant Scientific N.I.). S. Typhimurium SE10/72 was resuscitated by adding one bead to tryptone soy broth (Oxoid, Basingstoke, UK) plus 0.6\% (w/v) yeast extract (Oxoid) and incubating at $37{ }^{\circ} \mathrm{C}$ for $24 \mathrm{~h}$. Working cultures were maintained on TSAYE slants at $4{ }^{\circ} \mathrm{C}$. Working cultures were prepared by inoculation of MHB with a loopful of culture from a slope and incubating at $37^{\circ} \mathrm{C}$, for another 24 h. C. perfringens ATCC $^{\circledR}$ $13124^{\text {TM }}$ was similarly resuscitated into anoxic Müeller Hinton broth (MHB) and then incubated anaerobically at $37{ }^{\circ} \mathrm{C}$ for $24 \mathrm{~h}$. Working cultures were maintained on cooked meat medium at $4{ }^{\circ} \mathrm{C}$ for 30 days. Working cultures were prepared by inoculation of MHB with $20 \mu \mathrm{l}$ of overnight culture grown anaerobically at $37{ }^{\circ} \mathrm{C}$ in a cooked meat medium. To create anaerobic conditions, Anaerogen $^{\mathrm{TM}}$ (Thermo Scientific $^{\mathrm{TM}}$ Oxoid $^{\mathrm{TM}}$ ) sachets were added to the 2.5 litter jar specified to maintain anaerobiosis. Thorough all experimental procedures, the C. perfringens ATCC $^{\circledR} 13124^{\mathrm{TM}}$ strain was maintained and grown under anoxic environmental condition. The antimicrobial mixture, Auraguard, contained: $5 \%$ maltodextrin, $1 \%$ sodium chloride, $42 \%$ citric acid, $18 \%$ sodium citrate, $10 \%$ silica, $12 \%$ malic acid, $9 \%$ citrus extract and $3 \%$ olive extract $(\mathrm{w} / \mathrm{w})$. The raw materials were supplied by Bioscience Nutrition Ireland.

\section{Disc diffusion assay}

Briefly, $100 \mu \mathrm{l}$ of S. Typhimurium and C. perfringens bacterial cultures were spread onto Tryptone Soya Agar plus yeast extract (TSAYE Oxoid, UK), and C. jejuni was plated on Blood Agar Base Nr. 2 (BAB, Oxoid Ltd., United Kingdom) enriched with $5 \%$ (vol/vol) defibrinated horse blood (Aquilant Scientific N.I.). Next, the antimicrobial product was diluted in tenfold increments from $100 \%$ to $0.078 \%(\mathrm{v} / \mathrm{v}$ ) in MHB and $20 \mu \mathrm{l}$ of corresponding antimicrobial concentration was absorbed on $6 \mathrm{~mm}$ paper discs (Oxoid, UK). Antimicrobial activity of each antimicrobial was evaluated by the disc diffusion method according to the measuring of the diameter of the inhibition zone around the disc for each of antimicrobial concentrations used.

\section{Determination of minimum inhibitory and minimum bactericidal concentration}

The two-fold tube dilution method was used to determine the lowest concentration of Auraguard that inhibited bacterial growth (MIC) and the lowest concentration that induced bacterial death (MBC) was evaluated [50]. Auraguard was diluted ( $8 \%$ to $0.015625 \% \mathrm{v} / \mathrm{v}$ ) in Müeller Hinton broth (MHB) and thoroughly vortexed. Individual 
overnight bacterial cultures were harvested by centrifugation, washed twice in PBS, resuspended in MHB, and diluted to $1 \times 10^{6} \mathrm{CFU} / \mathrm{ml}$ in MHB. Each tube was inoculated with $5 \times 10^{5} \mathrm{CFU} / \mathrm{ml}$ of each bacterial culture (final concentration). Non-inoculated bijou $(5 \mathrm{ml})$ tubes containing the same growth medium were used as negative controls, whilst MHB tubes without Auraguard were inoculated with individual bacterial cultures as positive controls. Subsequently, $C$. jejuni tubes were incubated at $41.5^{\circ} \mathrm{C}$ for $48 \mathrm{~h}$, and C. perfringens and S. Typhimurium cultures were incubated at $37^{\circ} \mathrm{C}$ for $24 \mathrm{~h}$. Tubes that did not show visible growth were considered to be above the MIC. One hundred millilitres were taken from each tube for inoculation and then incubated at $37^{\circ} \mathrm{C}$ for $24 \mathrm{~h}$ onto TSAYE on Campylobacter Blood-Free Selective Agar Base (Modified CCDA-Preston; Oxoid Ltd., United Kingdom) under microaerophilic at $41.5^{\circ} \mathrm{C}$ for $48 \mathrm{~h}$. The highest dilution of each antimicrobial with no microbial growth was considered as the MBC [51]. The antimicrobial mixture was tested using concentrations from 8 to $0.0078 \%(\mathrm{v} / \mathrm{v})$ in three independent replicates repeated three times for each strain. In order to determine the subinhibitory concentrations used, all three pathogens were exposed to different concentrations of the antimicrobial mixture. The highest concentrations of antimicrobial that showed no effect on survivability and no growth inhibition (same growth kinetics as the control) were used in subsequent experiments [15].

\section{Infectivity assays}

The ECACC Madin-Darby Canine Kidney cells (MDCK) were grown in DMEM (Lonza, Analab Ltd., United Kingdom) supplemented with $10 \%$ foetal bovine serum. The cells were routinely grown in $75 \mathrm{~cm}^{2}$ tissue culture flasks (Sigma-Aldrich, Arklow, Ireland, SIAL0641) in a humidified incubator at $37{ }^{\circ} \mathrm{C}$ with $5 \% \mathrm{CO} 2$. The gentamicin protection assay was used to test the role of Auraguard towards the ability of $C$. jejuni RC039, S. Typhimurium SE $10 / 72$ and C. perfringens $\mathrm{ATCC}^{\circledR} 13124^{\mathrm{TM}}$ to adhere to and invade host epithelial cells as previously explained [52]. MDCK cells were grown (80-90\% confluence) for $22-24 \mathrm{~h}$ in six-well tissue culture plates at a concentration of $5.5 \times 10^{5}$ cells per well. The MDCK cell monolayers were pre-incubated with 0.25 and $0.5 \%$ Auraguard for $2-3 \mathrm{~h}$. The $\mathrm{pH}$ during all the experimental infections studies was maintained at neutral values $(\mathrm{pH}$ 7.2). Plate grown cultures of C. jejuni RC039, S. Typhimurium SE $10 / 72$ and C. perfringens ATCC $^{\circledR} 13124^{\mathrm{TM}}$ were harvested, washed, and re-suspended in tissue culture medium at an OD600 of $\approx 0.3$. The MDCK cells were washed twice with fresh culture media supplemented with $10 \%$ FBS, and $2 \mathrm{ml}$ of fresh culture medium was added to each well. Bacteria were added to give a multiplicity of infection of
100. Then, tissue culture plates were centrifuged at $250 \times g$ for $5 \mathrm{~min}$, and the plates with Campylobacter were incubated for $3 \mathrm{~h}$ at $41.5{ }^{\circ} \mathrm{C}$ in $85 \% \mathrm{~N}_{2}, 5 \% \mathrm{O}_{2}$ and $10 \% \mathrm{CO}_{2}$. Simultaneously, the six-well plates with Salmonella and Clostridia added for infection assays were subjected to $37^{\circ} \mathrm{C}$ incubation for $2 \mathrm{~h}$. To quantify the number of cellassociated bacteria, infected monolayers were washed three times with PBS and treated with $0.1 \%$ Triton X-100 in PBS at $41.5^{\circ} \mathrm{C}$ and $37^{\circ} \mathrm{C}$ for $15 \mathrm{~min}$. Ten-fold dilutions from each well were plated onto CCDA, and TSAYE agar (depending on bacteria culture) and the colonies were enumerated after 2 days of incubation at $41.5{ }^{\circ} \mathrm{C}$ in $85 \%$ $\mathrm{N}_{2}, 5 \% \mathrm{O}_{2}$, and $10 \% \mathrm{CO}_{2}$ or at $37^{\circ} \mathrm{C}$ respectively. In order to inhibit the ERK signal transduction pathway $30 \mu \mathrm{M}$ of PD98059 (Sigma-Aldrich, UK) was added to the infection plate $60 \mathrm{~min}$ prior to infection. The infected monolayers were washed with tissue culture medium to quantify the number of bacteria that invaded MDCK cells. Fresh medium $(2 \mathrm{ml})$ containing gentamicin $(400 \mu \mathrm{g} / \mathrm{ml})$ was added to kill bacteria that were not internalized. Medium without gentamicin was introduced to quantify the number of bacteria that adhered to the epithelial cells. Next, the tissue culture plates were incubated for a further $3 \mathrm{~h}$ at $41.5{ }^{\circ} \mathrm{C}$ or $37^{\circ} \mathrm{C}$ and washed with fresh DMEM $+10 \%$ FBS. MDCK cells were lysed by the addition of $1 \mathrm{ml}$ of $0.1 \%$ Triton X-100 in PBS and incubated for $15 \mathrm{~min}$ at $41.5^{\circ} \mathrm{C}$ or $37^{\circ} \mathrm{C}$. Tenfold dilution of each well content was plated onto CCDA and TSAYE agar, and colonies were enumerated after 1-2 days of incubation. Invasion efficiency was calculated as the percentage of the total number of CFU/total initial inoculum. All assays were conducted in triplicate on three separate days. The significance of differences in adhesion and invasion between samples was determined using the Student's t-test. A p-value of $<0.05$ was defined as significant.

\section{Transepithelial electrical resistance (TEER) and paracellular permeability measurements}

MDCK cells were plated onto transwells $\left(5 \times 10^{4} ; 6.5 \mathrm{~mm}\right.$ diameter; $0.4 \mu \mathrm{m}-$ pore size; Corning) and grown until apical junctional complexes developed. Transwells were infected apically with either C. jejuni RC039, S. enterica SE $10 / 72$ or $C$. perfringens ATCC ${ }^{\circledR} 13124^{\text {TM }}$. TEER was measured at $3 \mathrm{~h}$ after infection using an EVOM X meter connected to an Endohm chamber (World Precision Instruments). The paracellular permeability of MDCK cells was determined using calcein as the solute as described previously [53]. Flux assay data are presented as means (SD) of triplicate independent samples performed three separate times. The presented results are representative of at least three independent experiments. The mean (SD) of at least three independent experiments for each cell line was calculated. 


\section{Gene expression analysis}

The quantification of zonula occludens-1 (ZO-1) and occluding expression was performed as previously described with small modifications [26]. Briefly, the exposed or infected MDCK cells were snap-frozen in liquid nitrogen until use. RNA was isolated using RNeasy Plus Mini Kit (Qiagen, United Kingdom). The RNA was reverse transcribed using Transcriptor First Strand cDNA Synthesis Kit (Roche) according to the manufacturer's protocol. The mRNA levels were determined by quantitative RT-PCR using QuantiNovaSYBR Green PCR Kit (Qiagen, United Kingdom) on a LightCycler 96 (Roche). The primers used for ZO-1 were F: CGGGAC TGTTGGTATTGGCTAGA and R: GGCCAGGGCCAT AGTAAAGTTTG. For the occluding gene the primers used were F: TCCTATAAATCCACGCCGGTTC and R: CTCAAAGTTACCACCGCTGCTG. The gene expression was normalized using the ribosomal protein lateral stalk subunit P0 (RPLP0) and glyceraldehyde-3-phosphate dehydrogenase (GAPDH). The 2-DDCT method was used to analyse the relative expression (fold changes), calculated relative to the control group. In order to test the anti-inflammatory after LPS or Auraguard treatment we evaluated the expression of the following genes: IL-1 $\beta$, IL-6, IL-8, and TNF- $\alpha$. The expression of GAPDH gene was used as a control. The primers used were: for IL1- $\beta$ F-TGCAAAACAGATGCGGATAA, and R-GTA ACTTGCAGTCCACCGATT; IL-6, F-TCCAGAACA ACTATGAGGGTGA, R-TCCTGATTCTTTACCTTG CTCTT; IL-8, F-TGATTGACAGTGGCCCACATTGTG, R-GTCCAGGCACACCTCATTTC; TNF- $\alpha$, F-CGTCCA TTCTTGCCCAAAC, R-AGCCCTGAGCCCTTAATT $\mathrm{C}$ and for GADPH, F-TTCCACGGCACAGTCAAG, R-ACTCAGCACCAGCATCAC. The relative expression of the selected genes was calculated using the formula 2-DDCt with DCt values being represented as means of three test replicates [54].

\section{Intra and extracellular hydrogen peroxide $\left(\mathrm{H}_{2} \mathrm{O}_{2}\right)$ measurements in infected MDCK cells}

Hydrogen peroxide $\left(\mathrm{H}_{2} \mathrm{O}_{2}\right)$ production was measured using a Hydrogen Peroxide Detection Kit (Enzo Life Sciences) or Amplex ${ }^{\circledR}$ UltraRed /HRP (Thermo Fischer Scientific, UK) according to the manufacturers' instructions. Briefly, the lysis buffer or culture media $(50 \mathrm{ml})$ were mixed with the Amplex ${ }^{\circledR}$ UltraRed /HRP (Thermo Fischer Scientific, UK) reagent and with the horseradish peroxidase resulting in a red fluorescent oxidation product. Fluorescence was determined at $530 \mathrm{~nm}$ excitation and $590 \mathrm{~nm}$ emission using a fluorescence microplate reader (FLUOstar Omega, BMG Labtech). The concentrations of $\mathrm{H}_{2} \mathrm{O}_{2}$ were calculated using standard curves. For intracellular measurements, after treatment with
Auraguard the confluent cells were washed with phenol red free DMEM and incubated in the dark for $10 \mathrm{~min}$ in Krebs-Ringer solution containing $2^{\prime}, 7^{\prime}$-dichlorofluorescin diacetate (DCF-DA; Sigma Aldrich, UK). Cell cultures treated with diatrizoate $(6 \%)$ or ioxag- late $(10 \%)$ were detached from culture flasks, counted $\left(1 \times 10^{6}\right.$ cells $)$, and re-suspended in $800 \mu \mathrm{l}$ of PBS. A solution of DCFH $(200 \mu \mathrm{l})$ at final concentration $20 \mu \mathrm{mol} / \mathrm{ml}$ were added to the samples and incubated with agitation at $37{ }^{\circ} \mathrm{C}$ for $30 \mathrm{~min}$. The cells were centrifuged, resus- pended in EDTA, and carried out for fluorescence activated cell sorting (FACS) analysis. The values were averaged to obtain the mean relative fluorescence intensity, and the means were compared with each well. All experiments were repeated three times.

\section{Western blotting}

The infected cells, treated or un-treated with Auraguard, were boiled with SDS-PAGE loading buffer. Protein samples $(40 \mu \mathrm{g})$ were subjected to SDS-PAGE and further transferred on nitrocellulose membranes. The membranes were blocked with $5 \%$ dried milk in Tris-buffered saline and Tween-20 (TBST, $20 \mathrm{mM}$ Tris-HCl, $150 \mathrm{mM}$ $\mathrm{NaCl}, 0.05 \%$ Tween-20) for $6 \mathrm{~h}$ at room temperature. After washed with TBST, incubating the membranes in respective primary antibody solution (anti-phospho-ERK and anti- $\beta$-actin antibody, from Santa Cruz Biotechnology) overnight at $4^{\circ} \mathrm{C}$. After extensive washing, the membranes were then incubated with HRP-conjugated secondary antibody solution for $1 \mathrm{~h}$ at room temperature. The membranes were washed three times with TBST and the blots were detected by using enhanced chemiluminescence reagent (ECL) and exposed to photographic films (Kodak, Thermo Fischer, UK). Images were collected and the bands corresponding to phospho-ERK protein were quantitated by densitometric analysis using the E-Gel Imager from Life Technologies. Data of phospho-ERK were normalized on the basis of $\beta$-actin levels.

\section{Measurement of tetrathionate production}

MDCK cells were plated onto transwells $\left(5 \times 10^{4} ; 6.5 \mathrm{~mm}\right.$ diameter; 0.4 -pore size; Corning). Transwells were infected apically with either C. jejuni RC039, S. enterica SE $10 / 72$ or $C$. perfringens ATCC ${ }^{\circledR} 13124^{\mathrm{TM}}$. The cells were infected as described above. Sodium thiosulfate was added in each infection transwell, 60 min after infection, at a concentration of $10 \mathrm{mM}$. For measurements of tetrathionate produced by MDCK cells infected or infected in the presence of Auraguard (0.25 for C. jejuni and $0.50 \%$ for S. enterica and C. perfringens) Dimethylsulfoxide or Phorbol 12-myristate 13-acetate (in Dimethylsulfoxide) was added to tissue culture media at a final concentration of $1 \%$ and $10 \mu \mathrm{g} / \mathrm{ml}$, respectively, and the 
cells were incubated for $3 \mathrm{~h}$ at $37^{\circ} \mathrm{C} 5 \% \mathrm{CO}_{2}$. All samples were filter sterilized, and analysed using ion pairing RPLC-MS as previously described $[44,55]$.

\section{Statistical analysis}

Statistical analyses were performed using GraphPad software. Data were represented as mean \pm SD. p-values $<0.05$ were considered statistically significant following estimations using the Student $t$ was used.

\section{Abbreviations}

PCR: Polymerase chain reaction; DNA: Deoxyribonucleic acid; MDBK: MadinDarby bovine kidney cells; PBS: Phosphate buffer saline; GIT: Gastrointestinal tract.

\section{Acknowledgements}

No applicable.

\section{Authors' contributions}

Conceptualization, NC, MD, GGP, AM, Data curation, PW, TC, NC; Formal analysis, IB, IP, LS, ML. Funding acquisition, NC; Investigation, IB, NC; PS, Methodology, IB, CK; Project administration, NC; Resources, LS; Writing - original draft, IB, NC; Writing - review \& editing, TC, IB, NC, OG.

\section{Funding}

This study was supported by a grant awarded to NC by Environtech, Dublin, Ireland.

\section{Availability of data and materials}

All data generated or analysed during this study are included in this published article.

\section{Declarations}

\section{Ethics approval and consent to participate}

Not applicable.

\section{Consent for publication}

No applicable.

\section{Competing interests}

The authors declare that they have no competing interests.

\section{Author details}

${ }^{1}$ Food Microbiology, Bacteriology Branch, Veterinary Sciences Division, AgriFood and Biosciences Institute, 18a Newforge Lane, Belfast BT9 5PX, Northern Ireland, UK. ${ }^{2}$ Faculty of Animal Science and Biotechnologies, University of Agricultural Sciences and Veterinary Medicine, 400372 Cluj-Napoca, Romania. ${ }^{3}$ Faculty of Bioengineering of Animal Resources, Banat University of Agricultural Sciences and Veterinary Medicine-King Michael I of Romania, 300645 Timisoara, Romania. ${ }^{4}$ Department of Infection Biology, Faculty of Infectious \& Tropical Diseases, London School of Hygiene \& Tropical Medicine, Keppel Street, WC1E 7HT, London, UK. ${ }^{5}$ Auranta, Nova UCD, Belfield, Dublin, Ireland. ${ }^{6}$ Department of Animal and Dairy Science, University of Georgia, Athens, GA, USA. ${ }^{7}$ Research Institute of University of Bucharest (ICUB), 300645 Bucharest, Romania.

Received: 2 March 2021 Accepted: 1 June 2021

Published online: 07 June 2021

\section{References}

1. Lee H, Yoon Y. Etiological agents implicated in foodborne illness world wide. Food Sci Anim Resour. 2021;41(1):1-7.
2. World Health O. WHO estimates of the global burden of foodborne diseases: foodborne disease burden epidemiology reference group 2007-2015. Geneva: World Health Organization; 2015. p. 2015.

3. Hellgren J, Hästö L, Wikström C, Fernström L-L, Hansson I. Occurrence of Salmonella, Campylobacter, Clostridium and Enterobacteriaceae in raw meat-Based diets for dogs. Vet Rec. 2019;184:vetrec-2018.

4. Jones JL, Wang L, Ceric O, Nemser SM, Rotstein DS, Jurkovic DA, et al. Whole genome sequencing confirms source of pathogens associated with bacterial foodborne illness in pets fed raw pet food. J Vet Diagn Invest. 2019;31(2):235-40.

5. Nyati KK, Nyati R. Role of Campylobacter jejuni infection in the pathogenesis of Guillain-Barré syndrome: an update. BioMed Res Int. 2013:2013:852195.

6. Martinez-Anton L, Marenda M, Firestone SM, Bushell RN, Child G, Hamilton Al, et al. Investigation of the role of campylobacter infection in suspected acute polyradiculoneuritis in dogs. J Vet Intern Med. 2018;32(1):352-60.

7. Reimschuessel R, Grabenstein M, Guag J, Nemser SM, Song K, Qiu J, et al. Multilaboratory survey to evaluate salmonella prevalence in diarrheic and nondiarrheic dogs and cats in the United States between 2012 and 2014. J Clin Microbiol. 2017;55(5):1350-68.

8. Lowden P, Wallis C, Gee N, Hilton A. Investigating the prevalence of Salmonella in dogs within the Midlands region of the United Kingdom. BMC Vet Res. 2015;11(1):239.

9. Ziese A-L, Suchodolski JS, Hartmann K, Busch K, Anderson A, Sarwar $F$, et al. Effect of probiotic treatment on the clinical course, intestinal microbiome, and toxigenic Clostridium perfringens in dogs with acute hemorrhagic diarrhea. PLoS ONE. 2018;13(9):e0204691.

10. Gohari IM, Parreira VR, Nowell VJ, Nicholson VM, Oliphant K, Prescott JF. A novel pore-forming toxin in type A clostridium perfringens is associated with both fatal canine hemorrhagic gastroenteritis and fatal foal necrotizing enterocolitis. PLOS ONE. 2015;10(4):e0122684.

11. Balta I, Stef L, Pet I, Ward P, Callaway T, Ricke SC, et al. Antiviral activity of a novel mixture of natural antimicrobials, in vitro, and in a chicken infection model in vivo. Sci Rep. 2020;10(1):16631.

12. Ch Stratakos A, Sima F, Ward P, Linton M, Kelly C, Pinkerton $L$, et al. The in vitro and ex vivo effect of Auranta 3001 in preventing Cryptosporidium hominis and Cryptosporidium parvum infection. Gut Pathog. 2017;9:49.

13. Kelly C, Gundogdu O, Pircalabioru G, Cean A, Scates P, Linton M, et al. The in vitro and in vivo effect of carvacrol in preventing campylobacter infection, colonization and in improving productivity of chicken broilers. Foodborne Pathog Dis. 2017:14(6):341-9.

14. Pinkerton L, Linton M, Kelly C, Ward P, Gradisteanu Pircalabioru G, Pet I, et al. Attenuation of vibrio parahaemolyticus virulence factors by a mixture of natural antimicrobials. Microorganisms. 2019;7(12):679.

15. Sima F, Stratakos AC, Ward P, Linton M, Kelly C, Pinkerton L, et al. A novel natural antimicrobial can reduce the in vitro and in vivo pathogenicity of T6SS positive campylobacter jejuni and campylobacter coli chicken isolates. Front Microbiol. 2018:9:2139.

16. Stratakos AC, Linton M, Ward P, Campbell M, Kelly C, Pinkerton L, et al. The antimicrobial effect of a commercial mixture of natural antimicrobials against Escherichia coli 0157:H7. Foodborne Pathog Dis. 2019;16(2):119-29.

17. Day MJ, Bilzer T, Mansell J, Wilcock B, Hall EJ, Jergens A, et al. Histopathological standards for the diagnosis of gastrointestinal inflammation in endoscopic biopsy samples from the dog and cat: a report from the World Small Animal Veterinary Association Gastrointestinal Standardization Group. J Comp Pathol. 2008;138(Suppl 1):S1-43.

18. German AJ, Hall EJ, Day MJ. Chronic intestinal inflammation and intestinal disease in dogs. JVet Intern Med. 2003:17(1):8-20.

19. Alemka A, Clyne M, Shanahan F, Tompkins T, Corcionivoschi N, Bourke B. Probiotic colonization of the adherent mucus layer of HT29MTXE12 cells attenuates Campylobacter jejuni virulence properties. Infect Immun. 2010;78(6):2812-22

20. Corcionivoschi N, Alvarez LA, Sharp TH, Strengert M, Alemka A, Mantell J, et al. Mucosal reactive oxygen species decrease virulence by disrupting Campylobacter jejuni phosphotyrosine signaling. Cell Host Microbe. 2012;12(1):47-59.

21. Rosseland CM, Wierod L, Oksvold MP, Werner H, Ostvold AC, Thoresen GH, et al. Cytoplasmic retention of peroxide-activated ERK provides survival in primary cultures of rat hepatocytes. Hepatology. 2005;42(1):200-7. 
22. Watson RO, Galan JE. Signal transduction in Campylobacter jejuni-induced cytokine production. Cell Microbiol. 2005;7(5):655-65.

23. Lu N, Malemud CJ. Extracellular signal-regulated kinase: a regulator of cell growth, inflammation, chondrocyte and bone cell receptor-mediated gene expression. Int J Mol Sci. 2019;20(15):3792.

24. McNab FW, Ewbank J, Rajsbaum R, Stavropoulos E, Martirosyan A, Redford PS, et al. TPL-2-ERK1/2 signaling promotes host resistance against intracellular bacterial infection by negative regulation of type I IFN production. J Immunol. 2013;191(4):1732-43.

25. Zhang L, Gao J, Barkema HW, Ali T, Liu G, Deng Y, et al. Virulence gene profiles: alpha-hemolysin and clonal diversity in Staphylococcus aureus isolates from bovine clinical mastitis in China. BMC Vet Res. 2018;14(1):63.

26. Toschi A, Rossi B, Tugnoli B, Piva A, Grilli E. Nature-identical compounds and organic acids ameliorate and prevent the damages induced by an inflammatory challenge in Caco-2 cell culture. Molecules. 2020:25(18):4296.

27. Kamdar K, Khakpour S, Chen J, Leone V, Brulc J, Mangatu T, et al. Genetic and metabolic signals during acute enteric bacterial infection alter the microbiota and drive progression to chronic inflammatory disease. Cell Host Microbe. 2016:19(1):21-31.

28. Buchholz KR, Stephens RS. The extracellular signal-regulated kinase/mitogen-activated protein kinase pathway induces the inflammatory factor interleukin-8 following Chlamydia trachomatis infection. Infect Immun. 2007;75(12):5924-9.

29. Wine E, Chan VL, Sherman PM. Campylobacter jejuni mediated disruption of polarized epithelial monolayers is cell-type specific, time dependent, and correlates with bacterial invasion. Pediatr Res. 2008:64(6):599-604.

30. Bilal S, Jaggi S, Janosevic D, Shah N, Teymour S, Voronina A, et al. ZO-1 protein is required for hydrogen peroxide to increase MDCK cell paracellular permeability in an ERK 1/2-dependent manner. Am J Physiol Cell Physiol. 2018;315(3):C422-31.

31. Welsh MJ, Shasby DM, Husted RM. Oxidants increase paracellular permeability in a cultured epithelial cell line. J Clin Invest. 1985;76(3):1155-68.

32. Van Itallie CM, Fanning AS, Holmes J, Anderson JM. Occludin is required for cytokine-induced regulation of tight junction barriers. J Cell Sci. 2010;123(Pt 16):2844-52.

33. Van Itallie CM, Tietgens AJ, Krystofiak E, Kachar B, Anderson JM. A complex of ZO-1 and the BAR-domain protein TOCA-1 regulates actin assembly at the tight junction. Mol Biol Cell. 2015;26(15):2769-87.

34. Ferlazzo N, Visalli G, Smeriglio A, Cirmi S, Lombardo GE, Campiglia P, et al. Flavonoid fraction of orange and bergamot juices protect human lung epithelial cells from hydrogen peroxide-induced oxidative stress. Evid Based Complement Alternat Med. 2015;2015:957031.

35. Janosevic D, Axis J, Bacallao RL, Amsler K. Occludin content modulates hydrogen peroxide-induced increase in renal epithelial paracellular permeability. J Cell Biochem. 2016;117(3):769-79.

36. Van Itallie CM, Fanning AS, Bridges A, Anderson JM. ZO-1 stabilizes the tight junction solute barrier through coupling to the perijunctional cytoskeleton. Mol Biol Cell. 2009;20(17):3930-40.

37. Basuroy S, Seth A, Elias B, Naren AP, Rao R. MAPK interacts with occludin and mediates EGF-induced prevention of tight junction disruption by hydrogen peroxide. Biochem J. 2006;393(Pt 1):69-77.

38. Hobbie S, Chen LM, Davis RJ, Galan JE. Involvement of mitogen-activated protein kinase pathways in the nuclear responses and cytokine production induced by Salmonella typhimurium in cultured intestinal epithelial cells. J Immunol. 1997;159(11):5550-9.

39. Keates S, Keates AC, Warny M, Peek RM Jr, Murray PG, Kelly CP. Differential activation of mitogen-activated protein kinases in AGS gastric epithelial cells by cag+ and cag- Helicobacter pylori. J Immunol. 1999:163(10):5552-9.
40. Tang P, Rosenshine I, Finlay BB. Listeria monocytogenes, an invasive bacterium, stimulates MAP kinase upon attachment to epithelial cells. Mol Biol Cell. 1994;5(4):455-64.

41. Zhang Q, Luan R, Li H, Liu Y, Liu P, Wang L, et al. Anti-inflammatory action of ambuic acid, a natural product isolated from the solid culture of Pestalotiopsis neglecta, through blocking ERK/JNK mitogen-activated protein kinase signaling pathway. Exp Ther Med. 2018;16(2):1538-46.

42. Patrick DM, Leone AK, Shellenberger JJ, Dudowicz KA, King JM. Proinflammatory cytokines tumor necrosis factor-alpha and interferon-gamma modulate epithelial barrier function in Madin-Darby canine kidney cells through mitogen activated protein kinase signaling. BMC Physiol. 2006;6:2.

43. Ribet $D$, Cossart P. How bacterial pathogens colonize their hosts and invade deeper tissues. Microbes Infect. 2015;17(3):173-83.

44. Winter SE, Thiennimitr P, Winter MG, Butler BP, Huseby DL, Crawford RW, et al. Gut inflammation provides a respiratory electron acceptor for Salmonella. Nature. 2010;467(7314):426-9.

45. Liu Y-W, Denkmann K, Kosciow K, Dahl C, Kelly DJ. Tetrathionate stimulated growth of Campylobacter jejuni identifies a new type of bi-functional tetrathionate reductase (TsdA) that is widely distributed in bacteria. Mol Microbiol. 2013;88(1):173-88.

46. Stratakos AC, ljaz UZ, Ward P, Linton M, Kelly C, Pinkerton L, et al. In vitro and in vivo characterisation of Listeria monocytogenes outbreak isolates. Food Control. 2020;107:106784.

47. Corcionivoschi N, Gundogdu O, Moran L, Kelly C, Scates P, Stef L, et al. Virulence characteristics of hcp (+) Campylobacter jejuni and Campylobacter coli isolates from retail chicken. Gut Pathog. 2015;7:20.

48. Parker CT, Huynh $S$, Quinones B, Harris $L$, Mandrell RE. Comparison of genotypes of Salmonella enterica serovar Enteritidis phage type 30 and 9c strains isolated during three outbreaks associated with raw almonds. Appl Environ Microbiol. 2010;76(11):3723-31.

49. Zhou H, Lepp D, Pei Y, Liu M, Yin X, Ma R, et al. Influence of pCP1NetB ancillary genes on the virulence of Clostridium perfringens poultry necrotic enteritis strain CP1. Gut Pathog. 2017;9(1):6.

50. Zhu H, Du M, Fox L, Zhu M-J. Bactericidal effects of Cinnamon cassia oil against bovine mastitis bacterial pathogens. Food Control. 2016;66:291-9.

51. Jonasson E, Matuschek E, Kahlmeter G. The EUCAST rapid disc diffusion method for antimicrobial susceptibility testing directly from positive blood culture bottles. J Antimicrob Chemother. 2020;75(4):968-78.

52. Corcionivoschi N, Clyne M, Lyons A, Elmi A, Gundogdu O, Wren BW, et al. Campylobacter jejuni cocultured with epithelial cells reduces surface capsular polysaccharide expression. Infect Immun. 2009;77(5):1959-67.

53. Caswell D, Jaggi S, Axis J, Amsler K. src family kinases regulate renal epithelial paracellular permeability barrier through an occludin-independent mechanism. J Cell Physiol. 2013;228(6):1210-20.

54. Capellini FM, Vencia W, Amadori M, Mignone G, Parisi E, Masiello L, et al. Characterization of MDCK cells and evaluation of their ability to respond to infectious and non-infectious stressors. Cytotechnology. 2020:72(1):97-109.

55. Leskova A, Pardue S, Glawe JD, Kevil CG, Shen X. Role of thiosulfate in hydrogen sulfide-dependent redox signaling in endothelial cells. Am J Physiol Heart Circ Physiol. 2017;313(2):H256-64.

\section{Publisher's Note}

Springer Nature remains neutral with regard to jurisdictional claims in published maps and institutional affiliations. 